\title{
INTERNATIONAL LAW AND THE PRACTICE OF LEGALITY: STABILITY AND CHANGE
}

\author{
Jutta Brunnée $e^{*}$ and Stephen J Toope $e^{* *}$
}

\begin{abstract}
Drawing on the practice-turn in constructivism and in international relations (IR) theory more generally, we argue that a particular approach to managing stability and change is inherent in, and indeed characteristic of, legality and the rule of law in international as in domestic law. Our "interactional law" framework places particular emphasis on what we call the "practice of legality". This concept is central to understanding how law can both enable and constrain state actions, and why international law is a distinctive language of justification and contestation. In turn, the focus on stability and change is helpful because it directly confronts some of the persistent doubts and assumptions about international law, in particular in relation to international politics. Our work is animated by the intuition that the dominant views in IR and international law scholarship underestimate international law's capacity to mediate stability and change, in part because they focus on the surface of law (treaties, statutes and so on) and external factors (interests, enforcement). They neglect the deeper structure of what makes norms "law", and the distinctive practices that account for both its relative stability and its capacity for change.
\end{abstract}

\section{INTRODUCTION}

The interplay between stability and change is hardly a new topic for lawyers. After all, the notions of stability and change encapsulate important dimensions of what we value in and expect from law. In one of the most frequently cited descriptions of law's functioning, Roscoe Pound observed that: ${ }^{1}$

Law must be stable and yet it cannot stand still. Hence all thinking about law has struggled to reconcile the conflicting demands of the need of stability and the need of change.

* Professor of Law and Metcalf Chair in Environmental Law. This article sketches a conceptual framework for an ongoing book project on stability and change in international law, supported by the Social Sciences and Humanities Research Council of Canada.

** Professor of Law and Vice-Chancellor, University of Cambridge.

1 Roscoe Pound Interpretations of Legal History (Cambridge University Press, Cambridge, 1923) at 1. 
Law is commonly associated with order, predictability, certainty and, by extension, stability. At the same time, because law is grounded in a society's shared understandings, it must also accommodate change as values evolve or new social, economic, technological or environmental challenges and opportunities arise. Hence the perception that law is about reconciling or balancing stability and change.

International lawyers have sought to stabilise the law through emphasis on formal sources, codification in treaties, constructs like jus cogens, or projects like constitutionalisation. ${ }^{2}$ Even in the fluid evolution of customary law, lawyers and judges seek out moments of norm "crystallisation". 3 There is also much legal commentary on the grand themes of change in the structure and content of international law, ${ }^{4}$ or exploring the rise of new actors or the emergence of new substantive areas such as environmental law, human rights law, or international criminal law. ${ }^{5}$ Very often, the impetus is to show that law has stabilised evolving norms and made them more effective. By contrast, a recent study sought to demonstrate that the traditional structures of formal law-making - and the move toward stability - may have become "shackles" that prevent needed change, leading actors to develop informal mechanisms of standard setting. ${ }^{6}$ Yet others view international law as too malleable, as available to justify virtually any change powerful actors demand. ${ }^{7}$ Still, surprisingly few international

2 See Stéphane Beaulac "The Rule of Law in International Law Today" in Gianluigi Palombella and Neil Walker (eds) Relocating the Rule of Law (Hart Publishing, Oxford, 2008) 197 at 206; Horace B Robertson Jr "The 1982 United Nations Convention on the Law of the Sea" (2008) 84 International Law Studies 111 at 118; Christos L Rozakis The Concept of Jus Cogens in the Law of Treaties (North Holland Publishing, New York, 1976) at ix; and Jeffrey L Dunoff and Joel P Trachtman "A Functional Approach to International Constitutionalization" in Jeffrey L Dunoff and Joel P Trachtman (eds) Ruling the World? Constitutionalism, International Law, and Global Governance (Cambridge University Press, Cambridge, 2009) 3 at 10.

3 In the foundational judgment on customary international law, the International Court of Justice adopted the terminology of "crystallisation": North Sea Continental Shelf Cases (Germany v Denmark and the Netherlands) (Judgment) [1969] ICJ Rep 3 at 38-39 and 55.

4 See Josef L Kunz The Changing Law of Nations: Essays on International Law (Ohio State University Press, Ohio, 1968); Wolfgang Friedmann Law in a Changing Society (2nd ed, Columbia University Press, New York, 1972); Antonio Cassese and Joseph HH Weiler Change and Stability in International Law-Making (Walter de Gruyter, New York, 1988); Rosalyn Higgins "International Law in a Changing International System" (1999) 58 CLJ 78; and Wilhelm G Grewe The Epochs of International Law (M Byers (translator), Walter de Gruyter, New York, 2000).

5 See Friedmann, above n 4, at 443-492; Edith Brown Weiss "The New International Legal System" in Nandasiri Jasentuliyana (ed) Perspectives on International Law (Kluwer Law International, London, 1995) 63; Higgins, above n 4; and Kate Parlett The Individual in the International Legal System: Continuity and Change in International Law (Cambridge University Press, Cambridge, 2011).

6 Joost Pauwelyn, Rames A Wessel and Jan Wouters "When Structures Become Shackles: Stagnation and Dynamics in International Lawmaking" (2014) 25 EJIL 733.

7 See Martti Koskenniemi From Apology to Utopia: The Structure of International Legal Argument (reissue with a new epilogue, Cambridge University Press, Cambridge, 2005). 
law scholars have engaged directly with the ways in which stability and change are mediated internally within the structures and processes of international law. ${ }^{8}$ Only now does there appear to be a surge of interest in the principles, processes and techniques through which international law calibrates stability and change. ${ }^{9}$

International Relations (IR) theory has been more attentive to issues of stability and change ${ }^{10}$ because of its ambition to predict the behaviour of states and other international actors. However, at least in its dominant rationalist manifestations, stability and change are not typically the focus of IR analysis, but rather the outcomes of independent variables such as balances of power, interests of various actors, and institutions. Like many of their international law counterparts, IR scholars often perceive international law to be unstable, fragile or fluid. The underlying assumption is that, when push comes to shove, when law bumps up against interests or power, it loses - it will not be made in the first place, it will be avoided or evaded, or not complied with. ${ }^{11}$

This dim view of international law is fed by the still dominant conception of law as an edifice that is built by certain "sources" of law and as hierarchical imposition of authority. And since the latter is largely absent, international law is seen as weak. ${ }^{12}$ On this view, international law has no inherent

8 There were some notable exceptions, of course. See for example Myres McDougal Studies in World Public Order (Yale University Press, New Haven, 1960) at 169 (coining the Yale School's understanding of international law as a "process of authoritative decisions"); and Thomas M Franck Fairness in International Law and Institutions (Clarendon Press, Oxford, 1995) at 7 (commenting that distributive justice favours change whereas procedural justice favours stability, and observing that the "tension between stability and change, if not managed, can disorder the system" with "fairness" being "the rubric under which this tension is discursively managed").

9 See Christina Binder "Stability and Change in Times of Fragmentation: The Limits of Pacta Sunt Servanda Revisited" (2012) 25 LJIL 909; Monika Ambrus and Ramses Wessel "Between Pragmatism and Predictability: Temporariness in International Law" (2014) NYIL 3; Sofia Rankordás "The Rule of Law Time After Time: Temporary Institutions Between Change and Continuity" (2014) 45 NYIL 67; Nico Krisch "Liquid Authority in Global Governance" (2017) 9 International Theory 237; Nico Krisch "The Paths of International Law: Stability and Change in the International Legal Order" The Graduate Institute, Geneva <www.graduateinstitute.ch>; and Ingo Venzke "Semantic Authority, Legal Change and the Dynamics of International Law" in Patrick Capps and Henrik Palmer Olsen (eds) Legal Authority Beyond the State (Cambridge University Press, Cambridge, 2018) 102.

10 Kenneth W Abbott and Duncan Snidal "Law, Legalization and Politics: An Agenda for the Next Generation of IR-IL Scholarship" in Jeffrey L Dunoff and Mark A Pollack (eds) Interdisciplinary Perspectives on International Law and International Relations: The State of the Art (Cambridge University Press, Cambridge, 2013) 33 .

11 See Peter Katzenstein, Robert O Keohane and Stephen D Krasner "International Organization and the Study of World Politics" (1998) 52 International Organization 645; and Jack L Goldsmith and Eric A Posner The Limits of International Law (Oxford University Press, Oxford, 2005).

12 David Bederman "Constructivism, Positivism, and Empiricism in International Law" (2001) 89 Geo LJ 469 at 473 . 
stability. It is contingent on interest and power; ${ }^{13}$ it is stable so long as those driving forces are stable, and it will change as they do. ${ }^{14}$ Even norm-interested IR scholars, such as the constructivists, display a surprisingly limited view of law's potential to mediate stability and change. Much constructivist scholarship relies on a positivistic, static account of international law. ${ }^{15}$ Some scholars have explored how norms are created through social action, suggesting a "norm cycle" that begins with norm entrepreneurship, sees a norm gain increasing traction and, for a successful norm, culminates in the internalisation of norms by international actors. ${ }^{16}$ International law, in these accounts, is often seen as the end point of the norm cycle, as evidence of internalisation. Similarly, when constructivist scholars examine what may account for actors' compliance with international norms, many tend to assume the existence of a stable norm against which conduct can be indexed. ${ }^{17}$ International law is understood as fixed rules, best exemplified by norms enshrined in treaties. ${ }^{18}$

However, the evolution of shared understandings and social norms is not a unidirectional process. More recent strands of constructivism have shown that norms emerge, change or fade through processes of social learning and contestation. ${ }^{19}$ Norms are neither inherently static, nor invariably dynamic. What is more, even when a norm is "stable", it is being dynamically supported by actors' practices. ${ }^{20}$ Yet, although such norms can change over time, they are relatively "fixed" and capable of guiding conduct. ${ }^{21}$

13 Goldsmith and Posner, above n 11.

14 Andrew T Guzman How International Law Works: A Rational Choice Theory (Oxford University Press, Oxford, 2008).

15 Jutta Brunnée and Stephen J Toope "Constructivism and International Law" in Jeffrey L Dunoff and Mark A Pollack (eds) International Law and International Relations: Synthesizing Insights from Interdisciplinary Scholarship (Cambridge University Press, New York, 2013) 119 at 125-129.

16 Martha Finnemore and Kathryn Sikkink "International Norm Dynamics and Political Change" (2001) 52 International Organization 887.

17 See Brunnée and Toope, above n 15, at 128.

18 See Ryan Goodman and Derek Jinks "How to Influence States: Socialization and International Human Rights Law" (2004) 54 Duke LJ 621; and Thomas Risse and Kathryn Sikkink "The Socialization of International Human Rights Norms into Domestic Practices: Introduction" in Thomas Risse, Steve C Ropp and Kathryn Sikkink (eds) The Power of Human Rights: International Norms and Domestic Change (Cambridge University Press, Cambridge, 1999) 1.

19 See Emanuel Adler Communitarian International Relations: The Epistemic Foundations of International Relations (Routledge, New York, 2005); and Antje Wiener A Theory of Contestation (Springer Verlag, Heidelberg, 2014).

20 Etienne Wenger Communities of Practice: Learning, Meaning, and Identity (Cambridge University Press, Cambridge, 1998).

21 Wayne Sandholtz "Explaining International Norm Change" in Wayne Sandholtz and Kendall Stiles (eds) International Norms and Cycles of Change (Oxford University Press, New York, 2009) 1. 
Drawing on the "practice-turn" in constructivism and in IR theory more generally, ${ }^{22}$ our interactional law framework provides a counterpoint to the largely static accounts of international law that still prevail in the interdisciplinary literature. We claim that a particular approach to managing stability and change is inherent in, and indeed characteristic of, legality and the rule of law in international as in domestic law. Therefore, to get at law's distinctiveness, ${ }^{23}$ and to understand the specifically legal interplay between stability and change, one must examine law's internal structure. A second crucial point is that legality must be practiced. For example, the conclusion of a treaty is often just the beginning of a long law-building process - the document alone ensures neither stability nor change in law. Third, a focus on internal traits and practices of legality allows full consideration of the formal sources of international law as well as the so-called soft norms that more and more are shaping international interaction involving an ever-wider range of actors.

Our framework places particular emphasis on what we call the "practice of legality". We argue that this concept is central to understanding how law can both enable and constrain state actions, and why international law is a distinctive language of justification and contestation. In turn, the focus on stability and change is helpful because it directly confronts some of the persistent doubts and assumptions about international law, particularly in relation to international politics. Our work is animated by the intuition that the dominant views in IR and international law scholarship underestimate international law's capacity to mediate stability and change, in part because they focus on the "surface" of law (treaties, statutes and so on) and external factors (interests, enforcement). They neglect the deeper structure of what makes norms "law", and the distinctive practices that account for its relative stability and capacity for change.

\section{INTERACTIONAL INTERNATIONAL LAW}

Over the last twenty years, we have developed what we call an "interactional" understanding of international law, connecting insights from IR constructivism and practice theory to the legal theory of Lon Fuller. ${ }^{24}$ We were drawn to Fuller because, amongst twentieth-century legal theorists, he was

22 See Theodore R Schatzki "Practice Theory" in Theodore R Schatzki, Karin Knorr Cetina and Eike von Savingy (eds) The Practice Turn in Contemporary Theory (Routledge, New York, 2002) 1; Emanuel Adler and Vincent Pouliot "International Practices: Introduction and Framework" in Emanuel Adler and Vincent Pouliot (eds) The Practice Turn in International Relations (Cambridge University Press, Cambridge, 2011) 3; and Christian Bueger and Frank Gadinger International Practice Theory: New Perspectives (2nd ed, Palgrave Macmillan, Basingstoke, 2018).

23 See Martha Finnemore "Are Legal Norms Distinctive?" (2000) 32 NYUJ Intl Law \& Pol 699.

24 See Jutta Brunnée and Stephen J Toope "International Law and Constructivism: Elements of an Interactional Theory of International Law" (2000) 39 Colum J Transnatl L 19; Jutta Brunnée and Stephen J Toope Legitimacy and Legality in International Law: An Interactional Account (Cambridge University Press, Cambridge, 2010); Jutta Brunnée and Stephen J Toope "Interactional International Law: An Introduction" (2011) 3 International Theory 307; Jutta Brunnée and Stephen J Toope "Interactional International Law and the Practice of Legality" in Emanuel Adler and Vincent Pouliot (eds) The Practice Turn in International Relations (Routledge, New York, 2002) 108; and Jutta Brunnée and Stephen J Toope "The Rule of Law in an 
the most clear in recognising and explaining the essential "horizontality" of law. ${ }^{25}$ This feature of his account is of particular interest to international lawyers because it confronts head-on the persistent critique that international law cannot be true law because it lacks many of the hierarchical structures of authority that are commonly seen to define law. Fuller illustrated that what is often assumed to be a vertical relationship (of authority and subordination) is better understood as a reciprocal relationship in which citizens "accept as law and generally observe" the promulgated body of rules and, in turn, are able to expect that the government will abide by and apply these rules. ${ }^{26}$ Constructivism provides useful insight into the emergence, maintenance and operation of social norms. ${ }^{27}$ In turn, practice theory illuminates the dynamic interplay between actors pursuing their ends and legal norms enabling, guiding or constraining them in these pursuits. ${ }^{28}$ More specifically, it helps us understand international law as a distinctive practice of justification and contestation.

Drawing on these influences, our framework has three interrelated elements. First, building on constructivist insights, we posit that legal norms can only arise in the context of social norms based on shared understandings. Second, what distinguishes law from other types of social ordering is not simply provenance from a particular source, but adherence to a series of criteria of legality most comprehensively described by Fuller: generality, promulgation, non-retroactivity, clarity, noncontradiction, not asking the impossible, constancy, and congruence between rules and official action. ${ }^{29}$ When norm creation meets these criteria and when, third, there exists what we call a practice of legality (norm application that also satisfies the legality requirements), actors can pursue their

Agnostic World" in Wouter Werner, Marieke de Hoon and Alexis Galán (eds) The Law of International Lawyers: Reading Martti Koskenniemi (Cambridge University Press, Cambridge, 2017) 137.

25 Lon L Fuller The Morality of Law (revised ed, Yale University Press, New Haven, 1969).

26 Lon L Fuller "Human Interaction and the Law" (1969) 14 Am J Juris 1 (reprinted in Kenneth I Winston (ed) The Principles of Social Order: Selected Essays of Lon L Fuller (revised ed, Hart Publishing, Oxford, 2001) 211).

27 See Brunnée and Toope, above n 15.

28 More recently, other international law and IR scholars have begun to pay attention to practice theory as a productive path to new insights into international law. See Jens Meierhenrich "The Practice of International Law: A Theoretical Analysis" (2013) 76 LCP 1; Ingo Venzke "Contemporary Theories and International Lawmaking" in Catherine Brölmann and Yannick Radi (eds) Research Handbook on the Theory and Practice of International Lawmaking (Edward Elgar Publishing, Cheltenham, 2016) 66; Tanja E Aalberts and Ingo Venzke "Moving Beyond Interdisciplinary Turf Wars: Towards an Understanding of International Law as Practice" in Jean d'Aspremont and others (eds) International Law as a Profession (Cambridge University Press, Cambridge, 2017) 287; Nicholas Lamp "The 'Practice Turn' in International Law: Insights from the Theory of Structuration" Moshe Hirsch and Andrew Lang (eds) Research Handbook on the Sociology of International Law (Edward Elgar Publishing, Cheltenham, 2018) (forthcoming); and Jeffrey L Dunoff and Mark A Pollack "International Judicial Practices: Opening the 'Black Box' of International Courts" (2018, manuscript on file with authors).

29 See Fuller, above n 25; and Colleen Murphy "Lon Fuller and the Moral Value of the Rule of Law" (2005) 24 Law and Philosophy 239 at 240-241. 
purposes and organise their interactions through law. These features and practices of legality are crucial to generating a distinctive legal legitimacy and a sense of commitment among those to whom law is addressed.

The notion of "congruence between rules and official action", which encapsulates the idea of a reciprocal relationship to which we averted above, merits a few additional observations. In this conception of reciprocity, law-givers can only expect that citizens will "accept as law and generally observe" the promulgated body of rules when they meet the requirements of legality. ${ }^{30}$ In turn, if they are to be guided by these rules, citizens must be able to expect that the government will also abide by and apply the rules. As well, actions of officials must be congruent with posited law, and consonant with the requirements of legality. ${ }^{31}$ More than that, law can guide self-directed human interaction only if relatively stable patterns of expectation (or shared understandings) emerge, and if law is anchored in them. On our reading, through dynamic participatory processes, law generates and must continue to maintain its own authority. There is no single point of origin for law, be it a rule of recognition, a Grundnorm or a presumed external morality created through divine revelation or right thinking. ${ }^{32}$

Another way of explaining processes that generate and maintain legal authority is that the criteria of legality are crucial in shaping the patterns of a practice of legality. According to an influential definition, practices consist of: ${ }^{33}$

... socially meaningful patterns of action which, in being performed more or less competently, simultaneously embody, act out, and possibly reify background knowledge and discourse in and on the material world.

In other words, background knowledge serves to frame particular practices and, in turn, these practices maintain the background knowledge that participants in the practice come to take for granted. ${ }^{34} \mathrm{We}$ suggest that the criteria of legality are the relatively stable but socially constructed background knowledge that constitutes the practice of international law. It is social construction that distinguishes

30 Fuller, above n 26, at 235.

31 Fuller, above n 25

32 See Jutta Brunnée and Stephen J Toope "Interactional Legal Theory, the International Rule of Law, and Global Constitutionalism" in Anthony Lang and Antje Wiener (eds) Handbook of Global Constitutionalism (Edward Elgar Publishing, Cheltenham, 2017) 170; and Jan Klabbers "Constitutionalism and the Making of International Law: Fuller's Procedural Natural Law" (2008) 5 No Foundations: Journal of Extreme Legal Positivism 84 at 106.

33 Adler and Pouliot, above n 22, at 6.

34 John R Searle The Construction of Social Reality (The Free Press, New York, 1995). 
them from a Hartian rule of recognition. ${ }^{35}$ They provide the meaningful content of legal interaction and allow for interpretation along similar standards. Crucially, in today's deeply diverse international society, these criteria imbue international law with a measure of universality, ${ }^{36}$ even in the face of differences, divisions and particularities. ${ }^{37}$

For the purposes of international law, where states are subjects, lawmakers and administrative agencies,${ }^{38}$ the notions of congruence and reciprocity highlight the fact that legality is a collective enterprise - an international practice. Indeed, what Fuller termed congruence, in our account plays a central role as the third element of interactional law: the practice of legality. It reveals that congruence is more than just "compliance" (conformity of conduct with a given rule), encompassing a wider range of practices (for example, legal argumentation, interpretation, contestation, implementation or enforcement measures) through which actors demonstrate adherence to the norm as well as support its legality. Hence, the congruence requirement can be met even when some actors violate or distort existing legal norms, provided that other participants in the legal system work to uphold those norms. Alternatively, depending on the circumstances, patterns of contestation may result in strengthened, modified or new norms. ${ }^{39}$ Widespread failures to respect and uphold a given legal norm, however, will eventually lead to its erosion. In short, our emphasis on the practice of legality highlights that law application, interpretation and enforcement are all part of a continuum that either supports and subtly adjusts, or undermines, legal norms. ${ }^{40}$

For international lawyers and IR scholars, our interactional framework provides a novel perspective on the role of practice in international law. Practice, of course, plays an important role in the prevalent formal accounts of international law. For example, one of the elements necessary for the existence of customary international law is widespread and consistent state practice in conformity with the norm in question. Or, in treaty law, the practice of treaty parties can lead to new

35 Compare Lamp, above n 28, at 20. See also HLA Hart The Concept of Law (Oxford University Press, Oxford, 1994) at 101.

36 Brunnée and Toope, above n 32; and Onuma Yasuaki International Law in a Transcivilizational World (Cambridge University Press, Cambridge, 2017) at 44 and 119.

37 See Anthea Roberts Is International Law International? (Oxford University Press, Oxford, 2017).

38 Jeremy Waldron "The Rule of International Law" (2006) 30 Harv J L \& Pub Poly 15 at 23 (Waldron uses the word "official". We prefer "agency" as it reveals the institutional rather than personal nature of the state).

39 See Machiko Kanetake and André Nollkaemper "The International Rule of Law in the Cycle of Contestation and Deference" in Machiko Kanetake and André Nollkaemper (eds) The Rule of Law at the National and International Levels: Contestation and Deference (Hart Publishing, Oxford, 2016) 445; and Wiener, above $n$ 19.

40 For a concrete illustration of these dynamics see Jutta Brunnée and Stephen J Toope "Norm Robustness and Contestation in International Law: Self-Defence against Non-State Actors" (2019) 4 Journal of Global Security Studies (forthcoming). 
interpretations and ultimately modifications of a treaty. However, rather than simply treating state practice as behavioural regularities, or as the day-to-day application of a pre-existing construct called "law", we posit that a distinctive practice of legality is required for law to exist and to be sustained over time. It is precisely the effort to identify the distinctive traits of legality and legal practice that distinguishes our work from much of the emerging scholarship applying practice theory to international law. ${ }^{41}$

\section{THE CENTRAL ROLE OF PRACTICE IN CALIBRATING STABILITY AND CHANGE}

Our interactional law framework allows comprehensive and nuanced appreciation of the dynamics of stability and change in international law. We want to be clear that our focus is not on how law provides stability or promotes change within specific issue areas in political communities. Rather, we aim to show that particular calibrations of stability and change are distinctive of legality. Nor are we looking to provide a comprehensive theory of social change. We take for granted that there are various triggers or motivators of social change, such as dramatic changes to material circumstances or effective norm entrepreneurship. ${ }^{42} \mathrm{We}$ are interested in how the requirements and practices of legality manage attendant pressures for change in the law, resisting or facilitating it.

The constructivist IR discussion of shared understandings reveals how social norms stabilise and how they shift. ${ }^{43}$ When linked to the criteria of legality, social norms can become relatively fixed as law. But that fixity is never permanent. We posit that when the shared social understandings in which legal norms are grounded erode, or undergo significant shifts, law too will be under pressure to adjust. Stable social norms, for example, are important contextual factors for legality, bearing on such traits as the clarity or reasonableness of law. The same is true for changes in social norms or material circumstances. Even the codification of a norm in a treaty does not guarantee the stability of law (although it does serve some of the markers of legality, such as promulgation or clarity, which in turn promote stability). It is only through a continuing practice of legality that existing norms are supported or adjusted through law's distinctive patterns of justification and contestation. Inversely, when a practice of legality degrades (i.e. the criteria of legality are no longer met in practice), legal norms can be undermined and destroyed.

41 See Meierhenrich, above n 28; Aalberts and Venzke, above n 28; and Dunoff and Pollack, above n 28.

42 See William Form and Niko Wilterdink "Social Change (Sociology)" (28 December 2017) Encyclopedia Britannica <https://www.britannica.com>; and KJ Holsti The Problem of Change in International Relations Theory (Institute of International Relations, University of British Columbia Working Paper No 26, December 1998).

43 Antje Wiener "The Dual Quality of Norms and Governance Beyond the State: Sociological and Normative Approaches to 'Interaction"' (2007) 10 Critical Review of International Social and Political Philosophy 47; and Sandholtz, above $\mathrm{n} 21$. 
This interactional explanation connects, and makes more coherent, a series of principles, processes and techniques in international law that support or promote stability and shape change in distinctive ways. The criteria of legality illustrate that legality (and the rule of law) is in large part about a particular type of stability and a particular approach to enabling, constraining and guiding change. It is important to distinguish two different levels at which the requirements of legality bear on stability and change in law. First, as we noted above, they constitute the "background knowledge" that is needed for legal practices to occur and for law to exist. Thus, while debates may rage about whether or not a given norm is law, or whether or not a given action is in conformity with international law, the parameters for that debate are stable. Participants in processes of legal justification and contestation take these parameters for granted as markers of competent legal argumentation and, by virtue of this routinised recourse to the requirements of legality, also maintain them as background knowledge. It is worth recalling that background knowledge is not the same as a rule of recognition because such knowledge must be dynamically sustained through practice. ${ }^{44}$

Second, we argue that the requirements of legality also serve to account for the relative stability of specific legal norms or legal regimes. For example, the criteria of generality, clarity and constancy over time each address the need for stability and, hence, predictability of the law. The requirement that law not ask the impossible also fosters stability, since unrealistic demands will prompt noncompliance, which will, sooner or later, unsettle the law. Promulgation can both promote stability and facilitate predictable, orderly change. In turn, the criteria of non-retroactivity and non-contradiction guard against particular types of change. The requirement of congruence, finally, is of a different quality. Whereas the other criteria of legality capture the specific ways in which law manages stability and shapes change, congruence reveals what it takes for law to be stable, and helps explain how it changes over time. It highlights that stable practices of legality are required to maintain specific norms as law and that lack of congruence can erode the law or, by partaking in the practices that produce new normative understandings, shift the law. Indeed, should practices of legality fade more pervasively, not only particular norms but also the background knowledge that maintains international law itself would come under pressure. Congruence, and the idea of the practice of legality, therefore, constitute the pivot point for both individual legal rules and the international rule of law.

Although, in operating at the second of the two levels highlighted above, the criteria of legality tend to favour stability of particular legal norms or legal regimes, the framework we describe is not inherently conservative. First, the specific form of legal stability we describe is rooted in interaction and reciprocity; it is therefore an open system and allows for the participation of a range of social actors. Second, the criteria of legality that promote stability also require transparency and accountability, thereby facilitating contestation. Third, the stabilising tendency of the criteria of legality is modulated by the requirement that the criteria, indeed all law, be grounded in shared social understandings, and by the demand that legal normativity be continually maintained through a practice

44 See Lamp, above n 28, at 20; Hart, above n 35; and Venzke, above n 9. 
of legality. Indeed, the discipline created through the criteria of legality can provide a predictable and reliable framework for promoting substantive change in law and may also facilitate the evolution of soft law.

\section{Figure 1:}

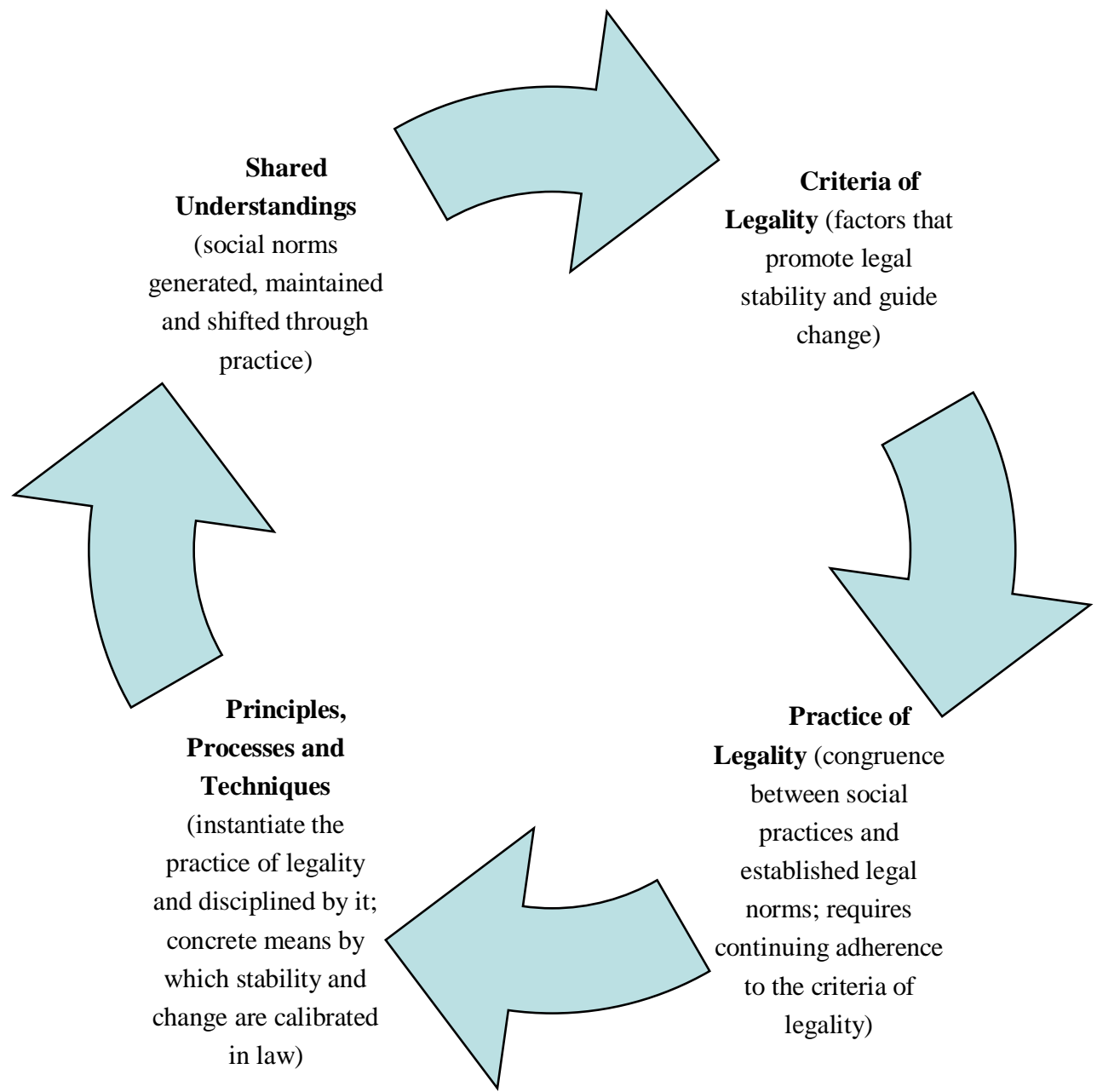

To sum up, in our description of the life-cycle of legal norms, norms emerge from shared understandings, but must meet the criteria of legality (a specific type of background knowledge) to qualify as law. Even then, legal norms, and the reciprocity upon which interactional law relies, require constant reinforcement through a continuing practice of legality if they are not to fall into desuetude 
or be actively destroyed. ${ }^{45}$ If the law deviates from the practices and understandings that prevail within society, it risks being unintelligible to actors - unclear or unreasonable, and impaired in its legality. When the conflict between a society's shared understandings and its legal rules is too stark, legality can come under significant strain. Actors' ability to rely on the law in their decision-making, and their commitment to the law, is fostered by adherence to the requirements of legality, especially congruence between official action and the law.

\section{MEDIATING BETWEEN STABILITY AND CHANGE IN INTERNATIONAL LAW}

In further developing these ideas for a monograph, we intend to focus on different modes of international law-making, examining customary law and treaty law formation through the optic of our interactional framework and assessing their roles in fostering stability and shaping change. In the context of this short article, we can offer only some preliminary observations. The interactional framework suggests that treaty law formation and customary law formation relate to the criteria of legality in different ways. Understanding the role that the criteria and practices of legality play also helps to show how so-called soft law can become interactional law, sometimes resembling custom and sometimes operating as a regime that partakes of treaty-like qualities.

For treaties, probably because they are explicit and textually grounded, the focus is very much on the manner in which principles, processes and techniques instantiate specific criteria of legality. Virtually all the background rules of treaty law, as articulated in the Vienna Convention on the Law of Treaties (VCLT), ${ }^{46}$ insist on the application of one or more of the criteria of legality. Hence, although the formality of treaty law is not enough to guarantee the stability of a treaty, it certainly furthers this goal, along with a range of other treaty law devices. For example, the requirement that treaties be set down in writing as well as the rules concerning entry into force of treaties and registration all serve the purpose of promulgation. ${ }^{47}$ Along with the rules that govern consent to be bound, entry into force, interpretation and amendments, the emphasis on written form also promotes

45 The figure is intended to capture the dynamism of international law and the interplay between the elements of our interactional account. However, the image oversimplifies the practice of international law in that the relationship between the elements we highlight is not unidirectional, as the circle-arrow image suggests. For example, a shift in shared understandings might impact directly on the practice of legality. Or the emergence of a practice of legality might turn a shared understanding into a norm that meets the criteria of legality. Furthermore, these patterns might unfold differently depending on the context of principles, processes and techniques (for example, in a treaty-based versus a customary law setting; or in a diplomatic versus a judicial dispute settlement process).

46 Vienna Convention on the Law of Treaties 1155 UNTS 331 (opened for signature 23 May 1969, entered into force 27 January 1980); and Brunnée and Toope Legitimacy and Legality, above n 24, at 49-50.

47 Articles 2(1)(a), 24 and 80. 
clarity, in relation to exactly when a state is bound by a treaty, exactly what the treaty requires, and exactly when its requirements change. ${ }^{48}$

Generality can be a challenge for treaty law, precisely because states must opt into treaties, may resort to reservations to tailor commitments, can decide whether or not to opt into amendments, and can withdraw from treaties. However, treaty provisions, such as entry-into-force regimes, ${ }^{49}$ tend to be designed to minimise picking and choosing of rules as much as possible. Similarly, in regulating reservations, amendments and withdrawal, treaty law serves to promote generality of obligations even as states are looking to use such devices to customise commitments. ${ }^{50}$

The fundamental rule of interpretation that words be given their ordinary meaning also enhances constancy over time, by connecting treaty terms to existing shared understandings and background knowledge. ${ }^{51}$ The amendment rules and the rules on termination or suspension of a treaty, in turn, promote constancy over time by managing the conditions under which states' rights and obligations under the treaty can be altered or extinguished. ${ }^{52}$ The value attached to constancy is also reflected in the principle of pacta sunt servanda and the rule on material breach, which also promote congruence between treaty norms and the subsequent practice of treaty parties. ${ }^{53}$

Finally, stability is promoted by a series of provisions that, by implementing the principles on non-contradiction and non-retroactivity, are intended to guard against certain types of change. The principle of non-contradiction is reflected in the rules on the application of successive treaties, the regime of contextual interpretation, the requirement that a treaty in more than one language must be interpreted authoritatively in each language - meaning that they must be read together, and the stipulation that a treaty is void when it conflicts with a peremptory norm of international law. ${ }^{54}$ The presumption of non-retroactivity imposes an explicit constraint on the application of treaties. ${ }^{55}$

In short, the emphasis on legality disciplines the specific devices through which treaties manage stability and change. Treaty law thereby imports the strong emphasis on stability that inheres in legality. It may be precisely this emphasis on stability that enables treaty law and practice to accommodate and promote change. For example, when institutional and procedural provisions of

\footnotetext{
48 Articles 7-17, 24, 31-33 and 39.

49 Articles 39-40.

50 Articles $19-23$ and 41

51 Article 31(1).

52 Articles 54-72.

53 Articles 26 and 60.

54 Articles 30, 31, 33, 53 and 64 .

55 Article 28.
} 
treaties meet the criteria of legality, they foster the emergence of robust procedural practices of legality. These practices, in turn, help provide a setting in which shared understandings on substantive matters can be deepened. The criteria of legality, precisely because they are largely neutral in substantive terms, enable parties with very different priorities and values to interact on the basis of legality. ${ }^{56}$

For custom, ${ }^{57}$ on the other hand, probably because it results primarily from practice, the focus tends to be upon how shared understandings emerge that undergird practice, and how a continuing practice of legality emerges that gives rise to or continues to support a customary norm. For example, whereas it is possible to produce formal treaty norms that are not grounded in shared understandings, one would assume that customary law cannot arise without widely shared understandings. In fact, however, the relevant understandings may be relatively thin among some states, seeing as it is typically a smaller number of interested states that engage in specific practice, while the inaction of other states counts as acquiescence. ${ }^{58}$ In turn, for customary law, the requirements of legality do not structure the rules concerning law-making as explicitly as they do for treaty law, and there continues to be debate on what exactly counts in the production of custom. ${ }^{59}$

And yet, legality is coded into customary law. After all, it is not enough for states' conduct simply to align with a given norm. In interactional law terms, that norm will emerge as customary law only when it is supported by robust practices of legality. ${ }^{60}$ This enriched form of practice is what traditionally has been called opinio juris. The interactional framework is frank that it is practice itself that grounds obligation but provides coherent criteria for evaluating that (physical or verbal) practice by asking whether it is rooted in the requirements of legality. Thus, the interactional law theory helps to dissolve the paradox of opinio juris in customary law-making. It offers a more objective account

56 Note, however, that a recent study has diagnosed a stagnation of treaty-based law-making processes, and a resultant increase in recourse to a wide range of alternative methods of soft standard setting: see Pauwelyn, Wessel and Wouters, above $n 6$.

57 This discussion of customary law draws on Jutta Brunnée "Sources of International Environmental Law: Interactional Law" in Samantha Besson and Jean d'Aspremont (eds) The Oxford Handbook on the Sources of International Law (Oxford University Press, Oxford, 2017) 960 at 969-970.

58 See Jonathan Charney "Universal International Law" (1993) 87 AJIL 529 at 538.

59 On the efforts of the International Law Commission to set out rules on the identification of customary law, see Michael Wood, Special Rapporteur Third report on identification of customary international law UN Doc A/CN.4/682 (27 March 2015).

60 See Brunnée and Toope Legitimacy and Legality, above n 24, at 47-48. 
of how a general practice can be recognised as "accepted as law", ${ }^{61}$ maintaining the distinction between social and legal norms. ${ }^{62}$

In drawing this distinction, the interactional account also brings some of the strengths and weaknesses of customary law-making into focus. For example, although the diffuse, fluid nature of the customary law-making process does not negate promulgation and clarity, it does make it harder to identify the precise point at which law arises than does treaty-making with its emphasis on written terms and detailed rules on entry-into-force. The prevailing metaphor of "crystallisation" is therefore misleading, not only because it suggests an easily identifiable moment when custom has come into being, but also because it masks the dynamism of norm-maintenance and further development. Like all law, customary international law gels; it does not crystalise.

Perhaps surprisingly, other requirements of legality will fare as well, possibly better, in customary than in treaty law. For example, customary law normally accords with the principles of generality and congruence. ${ }^{63}$ It also is less likely to make impossible demands and more likely to meet the constancy, non-contradiction and non-retroactivity requirements.

The customary law-making process is a subtle combination of unilateral acts - the practices of legality described above — and collective action — the requirement that practice must be widespread so as to serve as the foundation for custom. Hence, although customary law is inherently dynamic, it is also far more stable than one might assume at first glance. States' practices and legal opinions tend to maintain existing rules, and initiating a shift in the practices and views of a sufficient number of states to generate a new customary norm is relatively difficult. Furthermore, the need for any new norm to meet the criteria of legality establishes a discipline on assertions of emerging custom, even by powerful states. ${ }^{64}$

61 Article 38(1)(b) of the Statute of the International Court of Justice.

62 See also the International Law Commission's effort to set out rules on the identification of customary law: Wood, above n 59, at [13]-[18] (acknowledging the difficulties of separating practice and manifestations of opinio juris, while affirming the importance of both); and International Law Commission Identification of Customary International Law: Comments and observations received from Governments UN Doc A/CN.4/716 (14 February 2018).

63 However, at least historically, constructs like acquiescence facilitated the instantiation of customary norms that benefited some states more than others: see Yasuaki, above n 36, at 149-161 (arguing that the doctrines of customary international lawmaking have enabled powerful Western states to establish West-centric norms as universally valid law).

64 For a current example, consider the efforts of some Western states to establish the "unwilling or unable" standard as a trigger for the right to self-defence against non-state actors. See Jutta Brunnée and Stephen J Toope "Self-Defence Against Non-State Actors: Are Powerful States Willing But Unable to Change the Law?" (2018) 67 ICLQ 263. 
Since the interactional framework transcends the traditional distinction between hard and soft law, ${ }^{65}$ it can explain why some formally soft norms are "legal", while others are not. Soft law principles can become interactional international law if the criteria of legality are met, and if the resulting norms give rise to a continuing practice of legality. Inversely, the formal indicators of the existence of custom and treaty may not actually be adequate to produce interactional law; either can exist formally but be a dead letter in practice. An interactional law lens also allows the detailed exploration of an important phenomenon noted by others: the wider range of actors directly involved in the creation of legal norms, which expands the potential ambit of shared understandings. The active involvement of more parties allows, even requires, a wider range of mechanisms and devices to promote accountability and authenticity in the assertion of normative evolution. ${ }^{66}$

Our preliminary assessment is that the interactional law framework helps us appreciate why customary law is more stable, and treaty law more dynamic, than one might assume at first blush. Soft law can be dynamic or resilient, depending upon design of the regime. It is not as change-focused as many assume, but rather may be employed to provide stability in the absence of alternatives in formal law. A focus on practice is particularly instructive in explaining the necessity of stability and change in any legal system, including the international legal system.

\section{CONCLUSIONS}

In this short article, we have sketched out some of the main themes that we are exploring in our book project on stability and change in international law. We conclude with a series of hypotheses that we are looking to pursue and substantiate in that project:

(1) The most modest claim is that the requirements of legality promote stability and guide change (and that this is particularly evident in the context of treaty law).

(2) A related, slightly more ambitious point is that law manages stability and change in distinctive ways (through the criteria of legality) and the interactional law framework helps us see this more clearly. The inverse is also true: a specific approach to calibrating stability and change is distinctive of legality.

(3) A third, more provocative, conclusion is that we provide the beginning of an explanation of why interactional law is not as fluid as it may it may seem (practice-focused as it is) and why a more conventional account of law may both overstate what stability - say codification can provide and understate how stable and resilient law is in the face of state interests, power and politics.

65 For a nuanced discussion see Christine Chinkin "The Challenge of Soft Law: Development and Change in International Law" (1989) 38 ICLQ 850.

66 See Pauwelyn, Wessel and Wouters, above n 6. 
(4) Finally, and most ambitiously, we hypothesise that the interlocking elements of the interactional account (shared understandings, criteria of legality and practices of legality) provide the foundations of a theory of stability and change in law:

(a) The constructivist IR discussion of shared understandings illuminates how social norms emerge, stabilise and shift.

(b) When linked to what we refer to as the criteria of legality, social norms can become relatively fixed as law. But that fixity is never permanent. If the shared social understandings in which legal norms are grounded erode, or undergo a significant shift, law too will be under pressure to adjust.

(c) Stability and change in social norms, for example, are important contextual factors for legality, bearing on such traits as the clarity or reasonableness of law. Nonetheless, the criteria of legality do place strong emphasis on stability, and they serve to manage (enable, constrain, guide) legal change. Practice theory highlights that stability itself is dynamic, reminding us that it is only through a continuing practice of legality that existing norms are supported (or destroyed when the practice erodes).

(5) Importantly, then, it is not just any practice that creates law; there must be practice aligned with the criteria of legality if law is to be created:

(a) The criteria of legality serve to constrain and to enable actors to make law; constrain because the criteria are what makes practice distinctively legal; enable because the criteria make space for weaker actors to participate in the practices that shape law. Otherwise, raw power would define the existence or non-existence of seemingly legal norms.

(b) For the same reasons, we can say that law provides a distinctive language of justification and contestation. It enables and strengthens certain types of argument, but constrains and undercuts others.

(c) Furthermore, the requirements of legality can provide a predictable and reliable framework for promoting substantive change in law.

Invoking concepts of law requires us to think about stability and change. Law manages the timeless interplay between the need for predictability and certainty, and the need for dynamism and responsiveness, in unique ways. It does so through practices of legality that discipline social and political impulses, creating a rule of law that both facilitates and constrains change. 
